Situs Jurnal : $\underline{\text { http://ejurnal.stiepancasetia.ac.id/index.php/jieb }}$

Jilid 5 Nomor 1 Maret 2019

Hal $118-128$

\title{
ANALISIS STRATEGI PEMASARAN PADA BRI SYARIAH BANJARBARU
}

\section{Kahfi Al Abdhad*}

Abstract: This study aims to find out the marketing strategy at the Bank Rakyat Indonesia Syariah Branch of Banjarbaru so far and should. The study used a quantitative descriptive method with a SWOT analysis approach with a sample of 93 respondents. The results of the study can be concluded that the marketing strategy at the Bank Rakyat Indonesia Syariah Banjarbaru Branch which should be based on a SWOT analysis has the opportunity and strength, so that it can take advantage of the opportunities that exist. The strategy that must be applied in conditions in quadrant $\mathrm{I}$ is to support an aggressive strategy (growth oriented strategy), among others, expanding market share by expanding its wings outside the city of Banjarbaru which still has the potential, increasing cooperation with cooperatives in order to become partners and establish cooperation with educational institutions which is in Banjarbaru City.

Keywords: marketing strategy, SWOT, BRI Syariah Banjarbaru

Abstrak: Penelitian ini bertujuan ingin mengetahui strategi pemasaran pada Bank Rakyat Indonesia Syariah Cabang Banjarbaru selama ini dan yang seharusnya. Penelitian menggunakan metode deskriptif kuantitatif dengan pendekatan analisis SWOT dengan sampel sebanyak 93 responden. Hasil penelitian dapat disimpulkan bahwa strategi pemasaran pada Bank Rakyat Indonesia Syariah Cabang Banjarbaru yang seharusnya berdasarkan analisis SWOT dengan memiliki peluang dan kekuatan, sehingga dapat memanfaatkan peluang yang ada. Strategi yang harus diterapkan dalam kondisi berada di kuadran I adalah mendukung strategi agresif (growth oriented strategy) antara lain memperluas pangsa pasar dengan lebih melebarkan sayapnya di luar Kota Banjarbaru yang masih berpotensial, meningkatkan kerjasama dengan koperasi agar dapat menjadi partner dan menjalin kerjasama dengan lembaga pendidikan yang ada di Kota Banjarbaru.

Kata kunci : Strategi Pemasaran, SWOT, BRI Syariah Banjarbaru

\section{Latar Belakang}

Fungsi Bank Syariah itu sendiri yaitu menghimpun dana dari masyarakat dalam bentuk titipan dan investasi, menyalurkan dana kepada masyarakat yang membutuhkan dana dari bank, dan juga memberikan pelayanan dalam bentuk jasa perbankan syariah. Fungsi tersebut dapat dilakukan dengan berbagai akad, baik berdasarkan akad wadiah, murabahah, musyarakah, qardh dan lain sebagainya.

Bank sebagai lembaga keuangan perlu mengkomunikasikan setiap produk yang mereka tawarkan. Hal ini dilakukan agar masyarakat mengetahui dan memiliki minat membeli manfaat dari produk yang di tawarkan sesuai dengan kebutuhannya dan keinginannya. Banyak bank menawarkan produknya, baik produk baru atau suatu pengembangan dari produk lama. Diantara mereka ada yang gagal dan tidak sukses dalam merebut kepuasan konsumen. 
Perkembangan ekonomi syariah di masa sekarang ini dapat kita lihat begitu pesat, baik itu perkembangan di dalam negeri maupun di luar negeri. Di Indonesia khususnya perkembangan tersebut dapat kita jumpai dengan adanya bank-bank yang menggunakan prinsip syariah.

Saat ini industri jasa keuangan tengah mengalami transformasi yang sangat cepat dan dramatis. Dalam lingkungan pemasaran yang seperti ini, pemasaran efektif yang memiliki peranan sangat penting dalam menentukan apakah organisasi perusahaan akan bertahan, tumbuh, dan berkembang kokoh atau justru menurun dan gagal dalam mempertahankan daya saing organisasi perusahaannya.

Bank Syariah yang pada dasarnya bertujuan untuk meningkatkan kesejahteran masyarakat sehingga dengan produk pembiayaan yang ditawarkan. Akan tetapi mengingat kegiatan pemasaran dilaksanakan mulai pada perencanaan, penentuan produk, harga, distribusinya dengan maksud memuaskan kepentingan dan sesuai dengan kebutuhan konsumen atau nasabah. Dalam kegiatan pemasaran diperlukan juga konsep strategi, sehingga jasa dan produk yang ditawarkan dapat segera digunakan oleh nasabah. Strategi yang tepat dan disesuaikan dengan kebutuhan dan kemampuan masyarakat sebagai sasaran. Karena kegiatan tersebut tidak mudah, mengingat persaingan yang dihadapi di pasar sangat ketat, sehingga perbankan syariah dituntut untuk bergerak cepat dengan menetapkan strategi yang sesuai dengan kekuatan, kelemahan, peluang dan ancaman untuk bisa tetap bertahan hidup di tengah dunia persaingan yang semakin ketat.

Saat ini di Indonesia muncul dua jenis perbankan yang sedang bersaing satu sama lain dalam merebut perhatian pasar, yaitu perbankan syariah dan perbankan konvesional. Dalam beberapa hal, bank konvesional dan bank syariah memiliki persamaan terutama dalam sisi teknisi penerimaan uang, mekanisme transfer, teknologi komputer yang digunakan, syaratsyarat umum memperoleh pembiayaan, laporan keuangan dan lain sebagainya. Sama halnya dengan bank konvensional, Bank Syariah juga menawarkan kepada nasabahnya dengan berbagai produk perbankan. Produk - produk yang ditawarkan sudah tentu yang islami, termasuk dalam memberikan pelayanan kepada nasabahnya. Produk - produk Bank Syariah itu adalah : Funding / pendanaan, akad yang dipakai adalah wadi'ah dan mudharabah, dan financing/ pembiayaan, akad yang dipakai adalah jual beli, bagi hasil, sewa, dan pelayanan jasa lainnya.

Strategi pemasaran yang dilakukan oleh Bank Rakyat Indonesia Syariah Cabang Banjarbaru selama ini memasarkan produk yang dimiliki dengan strategi melalui pemasaran berbasis hubungan, kunjungan wiraniaga, penyebaran brosur dan edukasi. Namun strategi pemasaran yang dilakukan tersebut memiliki kendala, dimana masih adanya masyarakat yang belum mengetahui terhadap produk yang ditawarkan oleh Bank Rakyat Indonesia Syariah Cabang Banjarbaru dikarenakan pihak bank lebih sering menggunakan brosur.

Nasabah di Bank Rakyat Indonesia Syariah Cabang Banjarbaru pada tahun 2015 sampai tahun 2017 mengalami penurunan jumlah nasabah. Sehingga penelitian ini perlu mengkaji terhadap kelemahan, kekuatan, ancaman dan peluang di Bank Rakyat Indonesia Syariah Cabang Banjarbaru terkait penerapan strategi pemasaran yang dilakukan.

Agar penelitian ini lebih terarah dan terfokus kepada permasalahan yang muncul, maka penelitian ini dibatasi pada strategi pemasaran 4P (product, price, place dan promotion) pada Bank Rakyat Indonesia Syariah Cabang Banjarbaru yang seharusnya berdasarkan analisis SWOT. 


\section{Kajian Literatur}

Unsur-unsur dalam Marketing Mix terdiri dari beberapa strategi yang harus dijalankan secara kombinasi, meliputi:

1. Produk (product). Produk adalah barang atau jasa yang bisa ditawarkan di pasar untuk mendapatkan perhatian, permintaan, pemakaian, atau konsumsi yang dapat memenuhi keinginan atau kebutuhan. Pembeli akan membeli kalau merasa cocok. Karena itu, produk harus disesuaikan dengan keinginan ataupun kebutuhan pembeli agar pemasaran produk berhasil. Agar strategi produk dapat lebih efektif dalam rangka mempengaruhi konsumen untuk tertarik dan membeli kemudian mereka menjadi puas, maka harus mengetahui beberapa hal tentang strategi ini, yaitu :

a. Konsep produk. Konsep produk merupakan suatu pengertian atau pandangan konsumen terhadap suatu produk yang dibutuhkan dan diinginkannya. Konsumen akan memiliki konsep atau pandangan tertentu terhadap suatu barang.

b. Siklus kehidupan produk. Setiap produk sebenarnya akan memiliki siklus perputaran terhadap kehidupannya. Setiap produk itu sebenarmya dapat di ikuti perkembangan hidupnya seperti manusia saja, yaitu memiliki tahap-tahap anak-anak, kemudian tumbuh berkembang menjadi remaja, kemudian menjadi dewasa lalu surut menjadi tua dan akhirnya meninggal. Tahap yang paling awal dari masa hidupnya suatu produk dimulai dari suatu tahap yang disebut sebagai tahap perkenalan atau introduction. Pada masa ini produk tersebut baru diperkenalkan oleh pengusaha kepada masyarakat. Tahap berikutnya tahap pertumbuhan, di mana pada tahap ini merupakan kelanjutan dari tahap perkenalan yang berhasil. Setelah banyak anggota masyarakat yang mengenal akan produk itu maka diharapkan masyarakat tersebut akan menjadi menyenangi produk tersebut dan apabila hal ini terjadi maka produk tersebut akan berada pada tahap pertumbuhan. Tahap berikutnya lagi adalah menginjak pada tahap kedewasaan atau "Maturity". Tahap ini menunjukkan adanya masa kejenuhan di mana masyarakat atau konsumen sudah jenuh sehingga akan menjadi sukar untuk meningkatkan penjualan produk tersebut. Tahap yang terakhir adalah tahap penurunan atau "Decline". Dalam tahap ini masyarakat sudah tidak lagi menyenangi produk tersebut sehingga penjualan akan segera merosot tajam. Hal ini akan akan terjadi apabila pengusaha tidak mampu lagi untuk mempertahankan produknya pada tahap kedewasaan.

c. Jenis-jenis produk. Agar dapat memasarkan produk dengan baik maka perlu mengetahui produk itu termasuk dalam jenis yang mana, karena masing-masing jenis produk akan memerlukan penanganan yang berbeda dalam memasarkan produk tersebut agar berhasil.

2. Harga (Price). Pengusaha perlu memikirkan tentang penetapan harga jual produknya secara tepat karena harga yang tidak tepat akan berakibat tidak menarik para pembeli untuk membeli barang tersebut. Penetapan harga jual barang yang tepat tidak selalu berarti bahwa harga haruslah ditetapkan rendah atau serendah mungkin. Sering di jumpai bahwa apabila harga barang tertentu itu rendah maka banyak konsumen justru tidak senang karena dengan harga yang murah itu maka semua orang dapat memakai barang tersebut. Harga merupakan satu-satunya unsur marketing mix yang menghasilkan penerimaan penjualan, sedangkan unsur lainnya hanya unsur biaya saja. Walaupun penetapan harga merupakan persoalan penting, masih banyak perusahaan yang kurang sempurna dalam menangani permasalahan penetapan harga tersebut. Karena menghasilkan penerimaan penjualan, maka harga mempengaruhi tingkat penjualan, tingkat keuntungan, serta share pasar yang dapat dicapai oleh perusahaan. 
3. Distribusi (Place). Pengusaha haruslah menyebarkan barang-barangnya ke tempat konsumen itu berada. Hal ini merupakan tugas untuk mendistribusikan barangnya kepada konsumen. Untuk keperluan tersebut pengusaha dapat menggunakan berbagai bentuk saluran distribusi yang mungkin dilakukannya.

4. Promosi (Promotion). Promosi adalah merupakan kegiatan yang ditujukan untuk mempengaruhi konsumen agar mereka dapat menjadi kenal akan produk yang ditawarkan oleh perusahaan kepada mereka dan kemudian mereka menjadi senang lalu membeli produk tersebut. Adapun alat-alat yang dapat dipergunakan untuk mempromosikan produknya pengusaha dapat memilih beberapa cara yaitu :

a. Advertising (Periklanan). Advertising merupakan alat utama bagi pengusaha untuk mempengaruhi konsumennya. Advertising ini dapat dilakukan oleh pengusaha lewat surat kabar, radio, majalah, bioskop, televisi ataupun dalam bentuk poster-poster yang dipasang dipinggir jalan atau tempat-tempat yang strategis. Dengan membaca atau melihat advertising itu diharapkan para konsumen atau calon konsumen akan terpengaruh lalu tertarik untuk membeli produk yang diadvertesingkan tersebut. Oleh karena itu maka advertensi ini haruslah dibuat sedemikian rupa sehingga menarik perhatian para pembacanya.

b. Promosi penjualan (sales promotion). Promosi penjualan adalah merupakan kegiatan perusahaan untuk menjajakan produk yang dipasarkannya sedemikian rupa sehingga konsumen akan mudah untuk melihatnya dan bahkan dengan cara penempatan dan pengaturan tertentu maka produk tersebut akan menarik perhatian konsumen.

c. Personal selling (Penjualan pribadi). Personal selling merupakan kegiatan perusahaan untuk melakukan kontak langsung dengan para calon konsumennya. Dengan kontak langsung ini diharapkan akan terjadi hubungan atau interaksi yang positif antara pengusaha dengan calon konsumennya itu. Kontak langsung itu akan dapat mempengaruhi secara lebih intensif pada konsumennya karena dalam hal ini pengusaha dapat mengetahui keinginan dan selera konsumennya.

d. Publisitas (publication). Publisitas merupakan cara yang biasa digunakan juga oleh pengusaha untuk membentuk pengaruh secara tidak langsung kepada konsumen agar mereka menjadi tahu dan menyenangi produk yang dipasarkannya. Cara ini dilakukan dengan cara memuat berita tentang produk atau perusahaan yang menghasilkan produk tersebut di mass media, misalnya saja berita di surat kabar, berita di radio atau televisi maupun majalah tertentu dan sebagainya. Dengan memuat berita itu maka para pembaca secara tidak sadar telah dipengaruhi oleh berita tersebut.

SWOT adalah singkatan dari kata-kata Strength (kekuatan perusahaan) Weaknesses (kelemahan perusahaan), Opportunities (peluang bisnis) dan Threats (hambatan untuk mencapai tujuan). Analisis SWOT adalah analisis yang terdiri dari analisis lingkungan mikro yang bertujuan untuk mengetahui kekuatan dan kelemahan perusahaan, dan analisis lingkungan makro yang bertujuan untuk mengetahui peluang dan ancaman bagi perusahaan." Menurut Kotler (2015:88) mengemukakan bahwa analisis SWOT adalah evaluasi terhadap keseluruhan kekuatan, kelemahan, peluang dan ancaman.

Analisis SWOT merupakan salah satu instrument analisis yang biasa digunakan untuk mengidentifikasi berbagai faktor sistematis dalam merumuskan strategi suatu organisasi. Rangkuti (2014:172) menyatakan bahwa analisis SWOT di artikan sebagai akronim dari katakata strengths (kekuatan), weaknesses (kelemahan), opportunities (peluang) dan Threats (ancaman) adapun penjelasannya yaitu:

1. Faktor kelemahan, terdapat dalam tubuh suatu organisasi sedangkan peluang dan ancaman 
merupakan faktor-faktor lingkungan yang dihadapi oleh suatu organisasi ataupun perusahaan.

2. Faktor berupa kekuatan, dimiliki oleh suatu organisasi yaitu antara lain kompetensi khusus yang terdapat dalam suatu organisasi yang berakibat pada kepemilikan keunggulan kompetitif oleh unit usaha di pasaran. Dikatakan demikian karena suatu organisasi atau satuan bisnis memiliki sumberdaya, keterampilan, produk andalan lain-lain yang membuatnya lebih kuat dari para pesaing dalam memuaskan kebutuhan pasar yang sudah direncanakan.

3. Faktor peluang, yaitu berbagai situasi lingkungan yang menguntungkan bagi suatu bisnis.

4. Faktor ancaman, merupakan faktor lingkungan yang tidak menguntungkan bagi suatu organisasi. Jika tidak diatasi, ancaman akan menjadi ganjalan bagi suatu organisasi yang bersangkutan baik untuk masa sekarang, maupun di masa akan datang.

Sedangkan serangkaian kekuatan analisis SWOT adalah justru terletak pada pertumbuhannya mencapai taraf analisa yang mendalam, terfokus pada sasaran, serta secara sistematis membedah lingkungan internal maupun eksternal keorganisasian. Agar sanggup mewujudkan pencapaian tersebut dan untuk mampu memperoleh masukan-masukan yang berharga bagi proses-proses strategis pada suatu organisasi, maka suatu analisis SWOT perlu menghindari hal-hal yang tabu sebagai berikut:

1. Arahkanlah pada penanganan terstruktur, suatu analisis SWOT bukanlah sinonim dari musyawarah.

2. Hindarilah kesimpulan yang bertele-tele.

3. Hindarilah pemakaian kata-kata yang rancu dan bermakna ganda.

4. Hindarilah informasi yang bersifat garis besar dan kurang mendetil.

5. Usahakanlah senantiasa memverifikasi semua informasi dan opsi-opsi yang diperoleh untuk penelaahan validitasnya dan originalitasnya (apakah eligible atau tidak).

6. Usahakanlah senantiasa mengaitkan analisis hingga perolehan kesimpulannya (di mana upaya seperti ini merupakan langkah-langkah yang senantiasa konsisten dilakukan).

Menurut Higgins (dalam Rangkuti (2014:319) dalam rangka mencapai tujuan organisasi maka diperlukan suatu penguasaan informasi tentang berbagai masalah, baik dilingkungan internal maupun eksternal yang lazim dikenal dengan analisis SWOT yang meliputi Analisis Lingkungan internal dan Analisis Lingkungan Eksternal yaitu sebagai berikut:

1. Analisis lingkungan internal meliputi:

a. Strength (kekuatan), merupakan situasi dan kemampuan internal yang bersifat positif yang memungkinkan organisasi memiliki keuntungan strategis dalam mencapai tujuannya.

b. Weakness (kelemahan), merupakan situasi dan ketidak mampuan internal yang mengakibatkan organisasi tidak dapat mencapai tujuannya atau sebagai kondisi yang menempatkan organisasi pada ketidak beruntungan dan tidak kompetitif.

Kekuatan dan kelemahan sumber daya dalam organisasi dihubungkan dengan sumber daya persaingannya adalah sebagai berikut:
a. SDM.
b. Keadaan sumber keuangan.
c. Sarana dan prasarana yang dimiliki.
d. Perangkat organisasi yang dimiliki.
e. Loyalitas anggota. 


\section{f. Akses informasi. \\ g. Kepemimpinan}

2. Analisis Lingkungan Eksternal, meliputi:

a. Opportunities (peluang), adalah situasi dan faktor-faktor eksternal yang membantu organisasi dalam mencapai atau bahkan melampaui pencapaian sasarannya.

b. Threat (tantangan), adalah faktor-faktor eksternal yang menyebabkan organisasi tidak dapat mencapai sasarannya. Berdasarkan pengertian diatas maka dapat dinyatakan bahwa strategi dalam organisasi adalah serangkaian langkah yang ditempuh organisasi dengan melaksanakan analisis SWOT.

Analisis lingkungan internal dan analisis lingkungan eksternal dilakukan dengan alasan sebagai berikut:

1. Analisis SWOT merupakan analisis yang lengkap karena meliputi lingkungan internal dan lingkungan eksternal suatu organisasi, yang di dalamnya terdapat analisis terhadap kekuatan, kelemahan, peluang, dan tantangan yang dihadapi oleh suatu organisasi dalam melaksanakan aktivitas dan mencapai tujuan yang telah ditetapkan sebelumnya.

2. Melalui analisis SWOT ini akan diidentifikasi strategi yang perlu ditingkatkan dan diprioritaskan bagi suatu organisasi, karena didalamnya terdapat urutan mengenai strategi mana yang dipandang menjadi prioritas bagi organisasi untuk diterapkan setelah dikombinasikan antara kekuatan, kelemahan, peluang, dan tantangan organisasi.

\section{Metode Penelitian}

Jenis penelitian yang digunakan penulis dalam penelitian ini adalah penelitian deskriptif kuantitatif. Penelitian deskriptif kuantitatif adalah suatu pendekatan penelitian yang mengungkap situasi sosial tertentu dengan mendeskripsikan kenyataan secara benar, dibentuk oleh perhitungan dan kata-kata berdasarkan teknik pengumpulan data dan analisis data yang relevan yang diperoleh dari situasi yang alamiah.

Populasi adalah jumlah keseluruhan objek yang ingin diteliti. Populasi pada penelitian ini adalah keseluruhan nasabah yang memiliki tabungan pada Bank Rakyat Indonesia Syariah Banjarbaru pada tahun 2017 berjumlah 998 orang. Pengambilan sampel dalam penelitian ini menggunakan metode rumus Slovin sehingga responden yang dijadikan sampel yaitu 93 orang.

Jenis dan sumber data pada penelitian yang penulis lakukan sebagai berikut :

\section{Jenis Data}

Data yang dikumpulkan harus dapat dibuktikan kebenarannya, tepat waktu dan dapat memberikan gambaran yang menyeluruh. Maka jenis data yang digunakan adalah :

a. Data Kuantitatif, adalah data dalam bentuk angka yang dapat dihitung, yang diperoleh dari perhitungan kuesioner yang akan dilakukan yang berhubungan dengan masalah yang teliti.

b. Data Kualitatif, adalah data yang bukan dalam bentuk angka, yang diperoleh dari hasil wawancara dengan nasabah bank yang berhubungan dengan masalah yang teliti.

\section{Sumber Data}

Untuk menyusun suatu karya ilmiah diperlukan data, baik berupa data primer maupun data sekunder, yaitu akan dijelaskan sebagai berikut:

a. Data Primer, adalah data yang diperoleh penulis langsung dari responden nasabah tabungan di Bank Rakyat Indonesia Syariah Banjarbaru dalam bentuk wawancara serta 
tanggapan tertulis responden terhadap sejumlah pertanyaan yang diajukan dalam kuesioner penelitian.

b. Data Sekunder, adalah data pendukung yang diperoleh penulis dari beberapa sumber yang dinilai mempunyai relevansi dengan penelitian ini seperti review penelitian terdahulu, pendapat para ahli dan lain sebagainya.

Guna memperoleh data yang lengkap untuk menunjang penulisan ini, maka diadakan pengumpulan data melalui:

1. Penelitian Kepustakaan (library research), penelitian yang dilakukan dengan membaca literatur, laporan-laporan tertulis, dan bahan-bahan referensi lainnya sebagai landasan teori dalam penelitian.

2. Penelitian lapangan (field research), penelitian dengan mengadakan peninjauan langsung pada lokasi perusahaan dengan maksud memperoleh data primer dan informasi penting melalui observasi dan kuesioner.

a. Observasi, teknik pengumpulan data dengan cara mengamati dan meninjau secara langsung ke perusahaan yang diteliti.

b. Wawancara, teknik pengumpulan data dengan melakukan dialog secara langsung dengan konsumen.

c. Kuesioner, teknik pengumpulan data dengan cara memberi seperangkat pertanyaan atau pernyataan tertulis kepada responden atau nasabah.

Teknik analisis data yang digunakan dalam penelitian ini adalah secara deskriptif dengan pendekatan analisis SWOT. Analisis SWOT digunakan untuk merumuskan strategi pemasaran berdasarkan kekuatan, kelemahan, peluang dan ancaman Bank Rakyat Indonesia Syariah Banjarbaru. Tahap analisis dilakukan dengan membuat matrik IFAS (internal factors analisys summary) dan matrik EFAS (eksternal factors analisys summary). Matrik IFAS disusun berdasarkan kekuatan dan kelemahan yang dimiliki oleh Bank Rakyat Indonesia Syariah Banjarbaru, sedangkan matrik EFAS disusun berdasarkan peluang dan ancaman yang dihadapi oleh Bank Rakyat Indonesia Syariah Banjarbaru.

Setelah diketahui nilai dari matrik IFAS dan EFAS, maka tahap selanjutnya adalah melihat posisi perusahaan berdasarkan nilai matrik IFAS dan EFAS pada matrik IE (Internal Eksternal) yang digunakan untuk menentukan strategi pemasaran yang dapat digunakan oleh perusahaan. Sebuah penelitian yang menunjukan bahwa strategi pemasaran perusahaan dapat ditentukan oleh kombinasi faktor internal dan eksternal. Kedua faktor tersebut harus dipertimbangkan dalam analisis SWOT.

\section{Hasil Penelitian dan Pembahasan}

Strategi pemasaran pada Bank Rakyat Indonesia Syariah Cabang Banjarbaru selama ini, maka dapat dijelaskan strategi pemasaran perusahaan dapat ditentukan oleh kombinasi faktor internal dan eksternal. Kedua faktor tersebut harus dipertimbangkan dalam analisis SWOT. Analisis SWOT membandingkan antara faktor internal (IFAS) dan ekternal (EFAS) yang dapat dilihat pada tabel 1 . 
Tabel 1. Matriks IFAS Strategi Pemasaran Bank Rakyat Indonesia Syariah Cabang Banjarbaru

\begin{tabular}{|c|c|c|c|}
\hline Faktor Internal & Bobot & Rating & Skor \\
\hline \multicolumn{4}{|l|}{ Kekuatan (Strengths) } \\
\hline Citra Bank Rakyat Indonesia Syariah Banjarbaru sebagai bank yang baik & 0,10 & 3 & 0,30 \\
\hline $\begin{array}{l}\text { Produk yang ditawarkan telah sesuai dengan keinginan dan kebutuhan para } \\
\text { nasabahnya }\end{array}$ & 0,10 & 3 & 0,30 \\
\hline $\begin{array}{l}\text { Lokasi kantor Bank Rakyat Indonesia Syariah Banjarbaru yang letaknya } \\
\text { strategis }\end{array}$ & 0,11 & 3 & 0,33 \\
\hline Memiliki Sumber Daya Manusia (SDM) yang berkualitas & 0,10 & 3 & 0,30 \\
\hline \multirow[t]{2}{*}{ Memiliki bagi hasil yang kompetitif } & 0,10 & 3 & 0,30 \\
\hline & & & 1,53 \\
\hline \multicolumn{4}{|l|}{ Kelemahan (Weakness) } \\
\hline $\begin{array}{l}\text { Ketidaknyamanan dan kesulitan dalam bertransaksi dengan menggunakan } \\
\text { fasilitas } e \text {-banking }\end{array}$ & 0,10 & 3 & 0,30 \\
\hline Masih kurangnya ketersediaan kantor cabang pembantu dan kantor kas & 0,10 & 3 & 0,30 \\
\hline Masih kurangnya ketersediaan ATM & 0,10 & 3 & 0,30 \\
\hline $\begin{array}{l}\text { Brand image Bank Rakyat Indonesia Syariah Banjarbaru hanya diperuntukkan } \\
\text { bagi masyarakat muslim }\end{array}$ & 0,09 & 2 & 0,18 \\
\hline \multirow[t]{3}{*}{$\begin{array}{l}\text { Ketersediaan media periklanan baik media cetak, elektronik maupun media } \\
\text { sosial masih minim (internet) }\end{array}$} & 0,09 & 2 & 0,18 \\
\hline & & & 1,26 \\
\hline & 1,00 & & 2,76 \\
\hline
\end{tabular}

Untuk faktor eksternal ditemukan lima faktor eksternal yang berpengaruh positif adalah peluang dan lima faktor berpengaruh negatif adalah ancaman. Untuk penilaian faktor strategi eksternal tersebut digunakan model matriks External Factors Analysis Summary (EFAS), seperti tersaji pada Tabel 2.

Tabel 2. Matriks EFAS Strategi Pemasaran Bank Rakyat Indonesia Syariah Cabang Banjarbaru

\begin{tabular}{|c|c|c|c|}
\hline Faktor Eksternal & Bobot & Rating & Skor \\
\hline \multicolumn{4}{|l|}{ Peluang (Opportunities) } \\
\hline Masyarakat mulai tertarik terhadap sistem perbankan syariah & 0,12 & 4 & 0,48 \\
\hline $\begin{array}{l}\text { Masih luasnya pangsa pasar jasa keuangan dan perbankan syariah di Kota } \\
\text { Banjarbaru }\end{array}$ & 0,10 & 3 & 0,30 \\
\hline $\begin{array}{l}\text { Tingginya populasi penduduk yang beragama Islam di wilayah Kota Banjarbaru } \\
\text { dan sekitarnya }\end{array}$ & 0,10 & 3 & 0,30 \\
\hline $\begin{array}{l}\text { Menjalin kerjasama dengan pihak birokrasi maupun pihak swasta dalam } \\
\text { penggunaan layanan jasa dan produk }\end{array}$ & 0,10 & 3 & 0,30 \\
\hline \multirow[t]{2}{*}{ Perluasan jaringan Bank Rakyat Indonesia Syariah } & 0,10 & 3 & 0,30 \\
\hline & & & 1,68 \\
\hline \multicolumn{4}{|l|}{ Ancaman (Threats) } \\
\hline $\begin{array}{l}\text { Minimnya sumber daya manusia yang berkompeten dalam bidang perbankan } \\
\text { syariah }\end{array}$ & 0,10 & 3 & 0,30 \\
\hline Semakin lengkapnya fitur dan inovasi produk bank pesaing yang ditawarkan & 0,10 & 3 & 0,30 \\
\hline Banyaknya lembaga keuangan dan Bank Syariah di wilayah Kota Banjarbaru & 0,09 & 3 & 0,27 \\
\hline Semakin gencarnya promosi sesama kompetitor Bank Syariah & 0,09 & 3 & 0,27 \\
\hline \multirow[t]{2}{*}{ Keadaan perekonomian nasional maupun regional yang belum stabil } & 0,09 & 3 & 0,27 \\
\hline & & & 1,41 \\
\hline TOTAL & 1,00 & & 3,09 \\
\hline
\end{tabular}


Berdasarkan hasil analisis perbandingan kekuatan (S) dan kelemahan (W) dan peluang (O) dengan ancaman (T), maka dapat digunakan formulasi analisis SWOT sebagai berikut:

$$
\begin{array}{ll}
\mathrm{X} & =\mathrm{S}-\mathrm{W} \\
& =1,53-1,26=0,27 \\
\mathrm{Y} & =\mathrm{O}-\mathrm{T} \\
& =1,68-1,41=0,27
\end{array}
$$

Berdasarkan formulasi analisis SWOT terhadap strategi pemasaran pada Bank Rakyat Indonesia Syariah Cabang Banjarbaru, maka dapat digambarkan analisis SWOT pada diagram di Gambar 1.

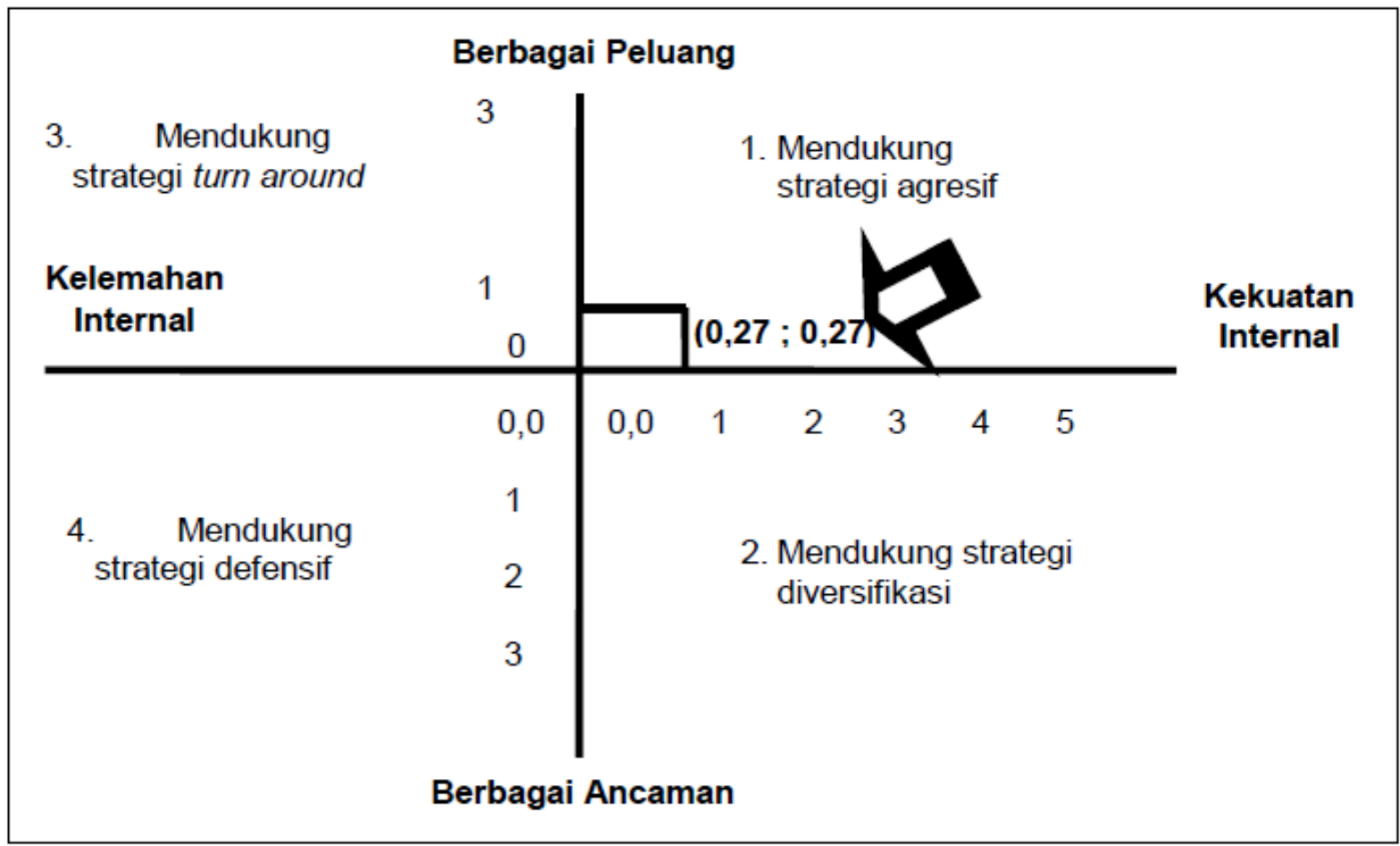

\section{Gambar 1. Formulasi Analisis SWOT}

Terlihat pada gambar diagram di atas titik potongnya berada pada sumbu X,Y $(0,27$; 0,27 ) berada pada diagram 1 dimana posisi tersebut merupakan situasi yang sangat menguntungkan. Bank Rakyat Indonesia Syariah Cabang Banjarbaru memiliki peluang dan kekuatan, sehingga dapat memanfaatkan peluang yang ada. Strategi yang harus diterapkan dalam kondisi ini adalah mendukung strategi agresif (growth oriented strategy), dimana menghadapi peluang pasar yang sangat besar, tetapi di lain pihak, ia menghadapi beberapa kendala atau kelemahan di internal Bank Rakyat Indonesia Syariah Cabang Banjarbaru. Menyikapi hasil kuadran berada diagram I dalam mendukung strategi agresif, maka Bank Rakyat Indonesia Syariah Cabang Banjarbaru dapat melaksanakan strategi meliputi:

1. Memperluas pangsa pasar dengan lebih melebarkan sayapnya di luar Kota Banjarbaru yang masih berpotensial. 
2. Meningkatkan kerjasama dengan koperasi agar dapat menjadi partner, agar koperasi yang ada di Kota Banjarbaru dapat menjadi nasabah Bank Rakyat Indonesia Syariah Cabang Banjarbaru.

3. Menjalin kerjasama dengan lembaga pendidikan yang ada di Kota Banjarbaru. Kota Banjarbaru disebut kota pelajar dikarenakan terdapat beberapa perguruan tinggi, sehingga kebanyakan perguruan tinggi tidak mau direpotkan oleh administrasi keuangan karena jumlah mahasiswanya begitu banyak.

Berdasarkan hasil identifikasi dengan menggunakan matriks IFAS dan matriks EFAS yang menggambarkan kekuatan dan kelemahan yang dimiliki Bank Rakyat Indonesia Syariah Cabang Banjarbaru serta peluang dan ancamanyang dihadapi oleh Bank Rakyat Indonesia Syariah Cabang Banjarbaru menggunakan matriks SWOT, maka diperoleh alternatif strategi dengan mengkombinasikan faktor-faktor internal dan eksternal Bank Rakyat Indonesia Syariah Cabang Banjarbaru Matriks SWOT menghasilkan empat tipe strategi diantaranya:

1. Strategi SO (Strenght-Opportunities), dimana strategi yang menggunakan kekuatan internal Bank Rakyat Indonesia Syariah Cabang Banjarbaru untuk memanfaatkan peluang yang ada. Strategi SO yang dapat dilakukan adalah meningkatkan kualitas produk dengan tetap mempertahankan sistem bagi hasil yang kompetitif, memberikan kenyamanan dan kemudahan dalam bertransaksi serta mengembangkan pemanfaatan teknologi internet banking dan mobile banking untuk memudahkan nasabah dalam melakukan transaksi dan meningkatkan loyalitas.

2. Strategi WO (Weakness-Opportunitiess), strategi kelemahan - peluang yaitu strategi yang bertujuan untuk memperbaiki kelemahan dengan memanfaatkan peluang yang ada. Strategi WO yang dapat diterapkan adalah dengan menambah kantor kas dan menambah jumlah ATM seluruh wilayah Kota Banjarbaru serta mengembangkan layanan internet banking dan mobile banking dan pula pemanfaatan media periklanan secara optimal dalam memasarkan produk Bank Rakyat Indonesia Syariah Cabang Banjarbaru.

3. Strategi ST (Strenghts-Threats), strategi yang menggunakan kekuatan untuk menghindari maupun mengurangi dampak ancaman dari faktor eksternal. Strategi ST yang diperoleh adalah mempertahankan kualitas sumber daya manusia untuk dapat memberikan pelayanan yang baik agar dapat menghadapi persaingan dan mempertahankan citra sebagai unit usaha syariah yang berpredikat baik dan terus meningkatkan kualitas pelayanan sehingga dapat bersaing dengan para kompetitor yang terus bertambah.

4. Strategi WT (Weakness-Threats), strategi untuk mengurangi kelemahan Bank Rakyat Indonesia Syariah Cabang Banjarbaru serta menghindari ancaman dari faktor eksternal. Strategi WT yang dapat dilakukan adalah melakukan promosi untuk mengimbangi promosi yang dilakukan sesama kompetitor dan memanfaatkan ketersediaan media periklanan untuk memasarkan produk Bank Rakyat Indonesia Syariah Cabang Banjarbaru.

\section{Kesimpulan}

Berdasarkan pada serangkaian hasil dari penelitian ini, dapat dibuat beberapa kesimpulan sebagai beirkut:

1. Strategi pemasaran pada Bank Rakyat Indonesia Syariah Cabang Banjarbaru selama ini menerapkan strategi pemasaran 4P, dimana (1) product memiliki karakteristik penghimpun dana dan pembiayaan, (2) price, untuk uang administrasi perbulan di Bank Rakyat Indonesia Syariah Cabang Banjarbaru lebih rendah dibandingkan dengan bank lainnya, baik yang syariah apalagi yang konvensional, (3) promotion, promosi yang dijalankan melalui cara periklanan (brosur, spanduk dan surat kabar lokal/daerah), (4) place, tempat mudah 
dijangkau masyarakat dengan kendaraan umum, berada di pusat atau jantungnya kota Banjarbaru.

2. Strategi pemasaran pada Bank Rakyat Indonesia Syariah Cabang Banjarbaru yang seharusnya berdasarkan analisis SWOT dengan memiliki peluang dan kekuatan, sehingga dapat memanfaatkan peluang yang ada. Strategi yang harus diterapkan dalam kondisi berada di kuadran I adalah mendukung strategi agresif (growth oriented strategy) antara lain memperluas pangsa pasar dengan lebih melebarkan sayapnya di luar Kota Banjarbaru yang masih berpotensial, meningkatkan kerjasama dengan koperasi agar dapat menjadi partner dan menjalin kerjasama dengan lembaga pendidikan yang ada di Kota Banjarbaru.

Saran masukan dari hasil penelitian ini:

1. Dalam menentukan strategi pemasaran, Bank Rakyat Indonesia Syariah Cabang Banjarbaru harus memanfaatkan kekuatan dan peluang yang dimiliki dengan tetap memandang faktor kelemahan dan ancaman. Jangan sampai kekuatan dan peluang berubah menjadi ancaman besar bagi bank sendiri.

2. Untuk menarik masyarakat agar menjadi nasabah, maka sosialisasi dan promosi harus selalu dilakukan baik secara tertulis maupun secara langsung, selain itu Bank Rakyat Indonesia Syariah Cabang Banjarbaru juga harus tetap meningkatkan pelayanan kepada nasabah, melengkapi fasilitas agar lebih memadai.

\section{DAFTAR PUSTAKA}

Alma, Sinta S, 2013, Konsep Pemasaran, Edisi Ketiga, Penerbit Rajagrafindo, Jakarta Assaury, 2013, Pengertian dan Mekanisme Pemasaran, Penerbit Pusaka Baru, Semarang Chandra, Novi Adi, 2015, Prinsip Pemasaran, Penerbit Pusaka Baru, Semarang Firdaus, 2013, Strategi Pemasaran Dalam Perusahaan Jasa, Penerbit Pusaka Baru, Semarang Gitosudarmo, Indriyo, 2013, Manajemen Pemasaran, Penerbit Salemba Empat, Jakarta Kotler, Philip, 2015, Manajemen Pemasaran, Penerbit Salemba Empat, Jakarta Rangkuti, 2014, Penjualan Jasa dan Barang, Penerbit Rajagrafindo, Jakarta Sunarto, 2013, Lingkungan Manajemen Pemasaran dan Aspeknya, Penerbit Rajagrafindo, Jakarta

Swastha, Basu dan Handoko, 2013, Manajemen Pemasaran, Penerbit Salemba Empat, Jakarta Tjiptono, 2013, Strategi dan Konsep Pemasaran, Penerbit Pusaka Baru, Semarang Usmara, 2013, Rumus Pemasaran, Penerbit Pusaka Baru, Semarang Yasid, Muhammad, 2015, Manajemen Pemasaran, Edisi Kelima, Penerbit Liberty, Jakarta 